\title{
Measurements of nitrous acid (HONO) in urban area of Shanghai, China
}

\author{
François Bernard ${ }^{1}$ • Mathieu Cazaunau ${ }^{1}$ - Benoît Grosselin ${ }^{1} \cdot$ Bin Zhou $^{2} \cdot$ Jun Zheng $^{3,6}$ • \\ Peng Liang ${ }^{1,4}$ - Yujie Zhang ${ }^{4}$ Xingnan $\mathrm{Ye}^{2}$ • Véronique Daële ${ }^{1}$ Yujing $\mathrm{Mu}^{4}$. \\ Renyi Zhang ${ }^{3}$ - Jianmin Chen ${ }^{2}$ Abdelwahid Mellouki ${ }^{1,5}$
}

Received: 30 June 2015 / Accepted: 10 November 2015 /Published online: 21 November 2015

(C) Springer-Verlag Berlin Heidelberg 2015

\begin{abstract}
Nitrous acid (HONO), as a precursor of the hydroxyl radical $(\mathrm{OH})$, plays an important role in the photochemistry of the troposphere, especially in the polluted urban atmosphere. A field campaign was conducted to measure atmospheric HONO concentration and that of other pollutants (such as $\mathrm{NO}_{2}$ and particle mass concentration) in the autumn of 2009 at Shanghai urban areas. HONO mixing ratios were simultaneously measured by three different techniques: long path absorption photometer (LOPAP), differential optical absorption spectroscopy (DOAS) and chemical ionization mass spectrometer (CIMS). The measurements showed that the
\end{abstract}

Responsible editor: Gerhard Lammel

Electronic supplementary material The online version of this article (doi:10.1007/s11356-015-5797-4) contains supplementary material, which is available to authorized users.

Abdelwahid Mellouki

mellouki@cnrs-orleans.fr

1 Institut de Combustion, Aérothermique, Réactivité et Environnement, Centre National de la Recherche Scientifique/ OSUC, 45071 Orléans cedex 02, France

2 Shanghai Key Laboratory of Atmospheric Particle Pollution and Prevention, Fudan Tyndall Centre, Department of Environmental Science \& Engineering, Fudan University, Shanghai 200433, China

3 Department of Atmospheric Sciences, Texas A\&M University, College Station, TX 77840, USA

4 Research Center for Eco-environmental of Sciences, Chinese Academy of Sciences, Beijing 100085, China

5 Environment Research Institute/School of Environmental Science \& Engineering, Shandong University, Shandong 250100, China

6 Present address: School of Environmental Science and Engineering, Nanjing University of Information Science and Technology, Nanjing 210044, China mixing ratios of $\mathrm{HONO}$ were highly variable and depended strongly on meteorological parameters. The HONO levels ranged from 0.5 to $7 \mathrm{ppb}$ with maximum values during early morning and minimum levels during late afternoon. The three instruments reproduced consistent diurnal pattern of HONO concentrations with higher concentration during the night compared to the daylight hours. Comparison of $\mathrm{HONO}_{\mathrm{LOPAP}} / \mathrm{HONO}_{\mathrm{CIMS}}$ ratios during daytime and nighttime periods exhibited a non-systematic disagreement of 0.93 and 1.16 , respectively. This would indicate different chemical compositions of sampled air for the LOPAP and the CIMS instruments during daytime and nighttime periods, which have possibly affected measurements. Mean HONO concentration reported by LOPAP was $33 \%$ higher than by DOAS on the whole period with no significant difference between daytime and nighttime periods. This revealed a systematic deviation from both instruments. The present data provides complementary information of $\mathrm{HONO}$ ambient levels in the atmosphere of Shanghai urban areas.

Keywords Nitrous acid · Ambient levels · Shanghai urban area $\cdot$ LOPAP $\cdot$ DOAS $\cdot$ ID-CIMS · Intercomparison

\section{Introduction}

The fast photolysis of nitrous acid (HONO) plays an important role in the tropospheric photochemistry, especially in the polluted urban areas, leading to the production of $\mathrm{OH}$ radicals and subsequently to ozone formation (Aumont et al. 2003; Stemmler et al. 2006; Volkamer et al. 2010). HONO photolysis could account for up to $30-60 \%$ of the morning $\mathrm{OH}$ production in urban areas (Alicke et al. 2003; Elshorbany et al. 2009). HONO present in the atmospheric boundary layer originates from homogenous and heterogeneous sources. 
Since the gas phase production of HONO from the reaction of $\mathrm{NO}$ with $\mathrm{OH}$ generally fails to explain the observed atmospheric HONO concentrations (Staffelbach et al. 1997; Aumont et al. 1999), additional sources originating from the heterogeneous chemistry have been also reported. This includes different surfaces (ground and aerosols) such as the photocatalytic conversion of $\mathrm{NO}_{2}$ on mineral dust (Ndour et al. 2008), the dark heterogeneous conversion of $\mathrm{NO}_{2}$ on suspended soot particles (Ammann et al. 1998; Arens et al. 2001), the heterogeneous hydrolysis of $\mathrm{NO}_{2}$ (Finlayson-Pitts et al. 2003), the photosensitized reduction of $\mathrm{NO}_{2}$ on organic surfaces (George et al. 2005; Stemmler et al. 2006), the photolysis of adsorbed nitric acid $\left(\mathrm{HNO}_{3}\right)$ (Zhou et al. 2003) and nitrate $\left(\mathrm{NO}_{3}{ }^{-}\right)$(Zhou et al. 2001), the $\mathrm{HNO}_{3}$ conversion on primary organic aerosols (Ziemba et al. 2010) and from soilemitted nitrite ( $\mathrm{Su}$ et al. 2011). Direct emissions from combustion processes (i.e. vehicles exhaust, biomass burning) also contribute, which may account for a large proportion of observed HONO in heavy polluted areas (Kirchstetter et al. 1996; Kurtenbach et al. 2001).

Atmospheric concentrations of HONO in Shanghai urban area have been recently reported in two studies (Hao et al. 2006; Wang et al. 2013). Both measurements have been carried out by the same differential optical absorption spectroscopy (DOAS) technique. Concentration levels of HONO reached a maximum of $\sim 7 \mathrm{ppb}$, in agreement with previous observations in other large cities (Winer and Biermann 1994; Febo et al. 1996; Qin et al. 2009). These measurements in Shanghai (China) showed that the combination of surface and relative humidity promoted the heterogeneous conversion of $\mathrm{NO}_{2}$ into $\mathrm{HONO}$ and would contribute to the observed concentration of HONO in the urban area of Shanghai (Hao et al. 2006).

Taking into consideration the important role of the HONO photodissociation in the atmosphere, various techniques have been developed and deployed for its atmospheric measurements, such as long path differential optical absorption spectroscopy (LP-DOAS) and chemical techniques (Febo et al. 1996; Spindler et al. 2003), long path absorption photometry (LOPAP) (Heland et al. 2001; Kleffmann et al. 2006) and ion-drift chemical ionization mass spectrometry (ID-CIMS) (Hirokawa et al. 2009; Levy et al. 2014). Time resolution, sensitivity, the absence of any artefact and the capability to perform measurements under diverse environmental conditions are paramount of importance in the performance of analytical instruments. Given that the increasing atmospheric interest in measuring HONO, intercomparison studies of instruments have been conducted in previous field measurements (Kleffmann et al. 2006; Stutz et al. 2010; Levy et al. 2014; Pinto et al. 2014). Excellent agreement between LOPAP and LPDOAS has been obtained (slope $=0.987 \pm 0.015 ; r^{2}=0.87$ ) (Kleffmann et al. 2006). The results of the comparison generally showed consistent agreement, although there were occasionally significant differences that could be attributed to either an $\mathrm{NO}_{2}$ artefact of the DOAS instrument or possible interferences in the chemical methods (Heland et al. 2001; Kleffmann et al. 2006; Stutz et al. 2010). CIMS is a powerful and sensitive technique in measuring many trace gases in the atmosphere. Previous HONO intercomparison studies reported that the CIMS measurements showed consistent agreement with other instruments in the morning, but differed significantly during the afternoon and the evening, exceeding the other measurements, likely due to interferences from unknown sources (Pinto et al. 2014).

In the present study, a field campaign was carried out to measure the concentrations of nitrous acid (HONO) and other pollutants $\left(\mathrm{NO}_{2}\right.$ and particle mass concentration) in Shanghai (China) during the last 2 weeks of October 2009. HONO mixing ratios were measured simultaneously by three measurement techniques (LOPAP, DOAS and CIMS) to characterize HONO concentration levels in the urban area of Shanghai. The objective of this work aimed to compare well-established techniques such as LOPAP, CIMS and DOAS in measuring HONO concentrations in Shanghai urban area.

\section{Methodology}

\section{Site description}

The field campaign took place in the northeast of Shanghai $\left(31.3^{\circ} \mathrm{N}, 121.5^{\circ} \mathrm{E}\right)$ on the roof $(\sim 20 \mathrm{~m}$ high $)$ of the $4^{\text {th }}$ Teaching Building on the campus of Fudan University (FDU). The area around the campus was representative for an urban area due to residential, traffic and construction activities. Handan Road, a trunk road with heavy traffic and with an expressway tunnel beneath, ran $300 \mathrm{~m}$ south of the site. Besides, there were a few branch roads around the campus. Figure S1 displays the sampling site at FDU.

\section{Description of measurement techniques}

\section{LOPAP (long path absorption photometer)}

LOPAP measurement operated from 14 to 29 October 2009. The LOPAP technique has been described in detail elsewhere (Heland et al. 2001; Kleffmann et al. 2002, 2006) and is briefly summarized here. The instrument was composed of two sections: a sampling unit and a detection unit. HONO was sampled in a stripping coil, undergoing fast conversion into an azo dye, which was photometrically detected using a long path absorption tube. The sampling section was composed of two glass coils in series where the first channel accounted for $\mathrm{HONO}$ and interferences and the second channel only for 
interferences assuming that more than $99 \%$ of HONO was converted into the first channel. HONO concentration was calibrated using a standard solution of $\mathrm{NO}_{2}{ }^{-}$(Titritisol Nitrite standard, $1000 \mathrm{mg} \mathrm{L}^{-1} \mathrm{NO}_{2}^{-}$in water). The instrument was calibrated three times over the measurement period. Automatic air zero measurements were performed during 45 min every $4-5 \mathrm{~h}$ to correct for zero drifts. The instrument was placed in a ventilated aluminium box. The temperature of the stripping coil was kept constant at $25{ }^{\circ} \mathrm{C}$ by a thermostat in order to ensure similar sampling conditions. A $2 \sigma$ detection limit of $10 \mathrm{ppt}$ was determined for a 1-min measurement with LOPAP. The measurement accuracy was $10 \%$.

\section{Active DOAS (differential optical absorption spectroscopy)}

DOAS measurements were conducted from 17 to 25 October 2009. Figure S2 illustrates the beam of the DOAS instrument running above Handan Road. The instrument has been described in details elsewhere (Yu et al. 2004; Hao et al. 2006; Wang et al. 2013). The light beam of DOAS for measurement ran above the campus and Handan Road. The transmitting/ receiving telescopes of DOAS were both set on the roof of about $20 \mathrm{~m}$ building. The retro-reflectors for DOAS were installed on the tall building of Yangpu High-tech Base at the altitude of $44 \mathrm{~m}$, with a horizontal distance of $680 \mathrm{~m}$ to the southeast of source building. Spectra in a wavelength range of $200-450 \mathrm{~nm}$ were recorded by a BWSpec (BRU741E-1024) spectrograph with a spectral resolution of $\sim 0.75 \mathrm{~nm}$ FWHM and detected by a 1024-pixel photodiode array detector. The average HONO concentrations along the optical path were analysed in the spectral region of 340 $370 \mathrm{~nm}$, with the cross sections of HONO (Stutz et al. 2000) and $\mathrm{NO}_{2}$ (Mérienne et al. 1995). Due to HONO impurities in the $\mathrm{NO}_{2}$ reference spectrum (typically $0.5 \%$ of the $\mathrm{NO}_{2}$ concentration), $\mathrm{HONO}$ concentration data were corrected using the measured $\mathrm{NO}_{2}$ concentration $\left([\mathrm{HONO}]_{\text {Corrected }}=[\mathrm{HONO}]_{\text {Measured }}{ }^{+}\right.$ $\left.0.005 \times\left[\mathrm{NO}_{2}\right]_{\text {Measured }}\right)$. The detection limits obtained for $\mathrm{HONO}$ and $\mathrm{NO}_{2}$ were $0.2 \mathrm{ppb}$ and 2 ppb $(3 \sigma)$, respectively, for 5-min averaged data. The measurement accuracy was estimated to be $10 \%$ for $\mathrm{NO}_{2}$ and $15 \%$ for $\mathrm{HONO}$.

\section{ID-CIMS (ion-drift chemical ionization mass spectrometer)}

ID-CIMS was operated from 14 to 20 October 2009. Details on the instrument can be found elsewhere (Fortner et al. 2004). HONO was measured by ID-CIMS using $\mathrm{SF}_{6}{ }^{-}$reagent ions. The signal was integrated for about $9 \mathrm{~s}$ per measurement cycle using single ion monitor mode. The instrument was zeroed with Nylon filter for 15 cycles every 100 measurement cycles. $\mathrm{HONO}$ was detected as $\mathrm{HONO} \cdot \mathrm{F}^{-}$complex. Its quantification was based on calibrations with gaseous HONO standards in situ generated by passing quantitatively permeated nitric acid through a $\mathrm{NaNO}_{2}$ (Sigma-Aldrich, $99.999 \%$ ) column. The detection limit $(2 \sigma)$ was $0.032 \mathrm{ppbv}$ (for 1-min averaged data). The accuracy was $\sim 13 \%$ based on five consecutive calibrations.

\section{Other measurement}

The photolysis frequency of $\mathrm{NO}_{2}, J_{\mathrm{NO} 2}$, was measured by a filter radiometer (Meteorologie consult gmbh, Germany). The acquisition time was fixed at $1 \mathrm{~s}$. The meteorological data, such as pressure, temperature, relative humidity, and wind speed/direction, were continuously monitored using a weather station (Oregon Scientific ${ }^{\mathrm{TM}}$, WMR100 model) every $1 \mathrm{~min}$. The absolute uncertainties were $\pm 1{ }^{\circ} \mathrm{C}$ for the temperature, $5-7 \%$ for the relative humidity and $\pm 3 \mathrm{~m} \mathrm{~s}^{-1}$ for $2-10 \mathrm{~m} \mathrm{~s}^{-1}$ wind speed range and $\pm 10 \%$ between 10 and $56 \mathrm{~m} \mathrm{~s}^{-1}$.

Particle mass concentration $\left(\mathrm{PM}_{1}, \mathrm{PM}_{2.5}\right.$ and $\left.\mathrm{PM}_{10}\right)$ was measured using an optical particle spectrometer (GRIMM Model 180, GRIMM Aerosol Technik GmbH, Germany). The data were recorded every $1 \mathrm{~h}$.

\section{Results and discussion}

\section{Measurements of HONO, other pollutants and meteorological parameters}

Figure 1 shows the time profiles of HONO mixing ratios measured by LOPAP, photolysis frequency of $\mathrm{NO}_{2}\left(J_{\mathrm{NO} 2}\right)$ and meteorological parameters (temperature, relative humidity and wind speed/direction) during the period 14-29 October 2009. $\mathrm{NO}_{2}$ was measured by DOAS (17-25 October) at FDU site and particulate matter mass concentrations $\left(\mathrm{PM}_{1}, \mathrm{PM}_{2.5}\right.$ and $\mathrm{PM}_{10}$ ) at Pudong district between 14 and 29 October. During the campaign, sunny weather conditions prevailed with a mean temperature of $21{ }^{\circ} \mathrm{C}$ ranging from 15.5 to $27.5^{\circ} \mathrm{C}$. The mean relative humidity was $48 \%$ reaching up to $96 \%$ during the night and down to $18 \%$ during the day. The wind speed ranged from 0 to $3.3 \mathrm{~m} \mathrm{~s}^{-1}$ leading to an average value of $0.9 \pm 0.6 \mathrm{~m} \mathrm{~s}^{-1}$. The mean maximum $J_{\mathrm{NO} 2}$ during the whole campaign was $7.8 \times 10^{-3} \mathrm{~s}^{-1}$.

Particle mass data were taken from Pudong Meteorological Station (about $9.3 \mathrm{~km}$ away from the FDU site) due to the absence of measurements at FDU site during the period of interest. Data reliability was confirmed in a separate study where the concentration of particles through visibility measurement were shown to be in agreement from simultaneous measurements at FDU and Pudong sites at similar period as this work ( $\mathrm{Li}$ et al. 2011). The average concentrations of $\mathrm{PM}_{1}$, $\mathrm{PM}_{25}$ and $\mathrm{PM}_{10}$ during the observation period were $41.6 \pm$ 26.7, $57.8 \pm 29.8$ and $98.9 \pm 42.9 \mu \mathrm{g} \mathrm{m}^{-3}$, respectively, higher than the US EPA 24-h standard $\left(35 \mu \mathrm{g} \mathrm{m}^{-3}\right)$ for $\mathrm{PM}_{2.5}$. PM 
Fig. 1 Time series of $\mathrm{HONO}$ (LOPAP measurement), $\mathrm{NO}_{2}$ (DOAS measurement), $\mathrm{NO}_{2}$ photolysis rate $\left(J_{\mathrm{NO} 2}\right)$ and meteorological parameters (temperature $(\mathrm{T})$, relative humidity (RH), wind speed (WS) and wind direction (WD)) during the observation period from 14 to 29 October 2009, in Shanghai, China

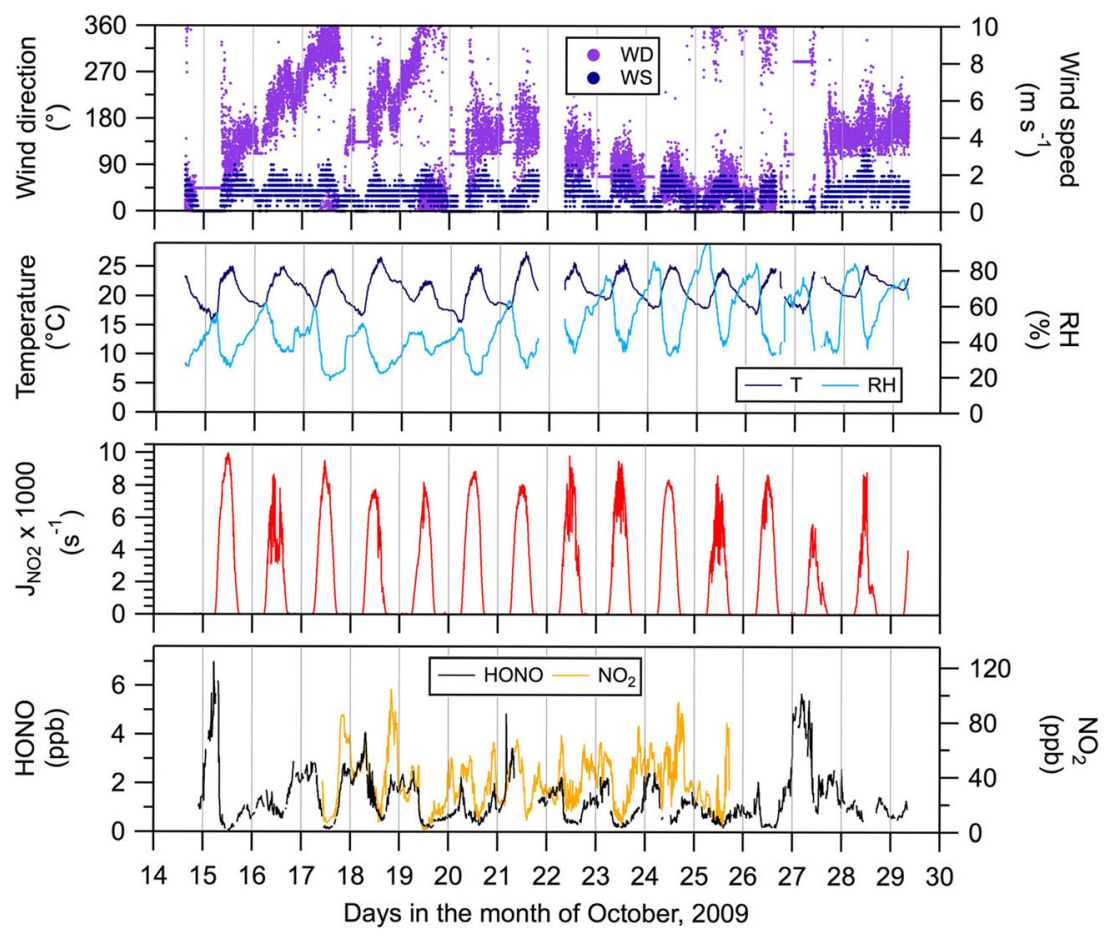

mass concentration levels during our observation period were comparable to those measured in Shanghai during MayJune 2010 (Huang et al. 2012).

HONO concentration was partially influenced by variations of meteorological conditions. Highest HONO mixing ratios were met in the early morning of 15 and 27 October when wind speeds dropped to zero, as shown in Fig. 1. The high HONO mixing ratios under the low wind speed might arise mainly from the HONO accumulations due to direct emissions and heterogeneous chemical reactions, and also related to the poor dispersion and the lower rate of removal. The wind speed on the whole measurement period remained relatively low favouring accumulation of pollutants. Different wind directions might cause different $\mathrm{HONO}$ mixing ratios in the investigated areas (Fig. 1). HONO mixing ratios were nearly zero when the wind speed was mainly from the northeast direction on 15 October and from west direction on 27 October. On the contrary, under other wind directions, the mixing ratios exhibited different levels due to the influence by both the local emissions and the transportation.

HONO mixing ratios exhibited typical diurnal patterns with maximum levels during late night and early morning and minimum values in the late afternoon. The daily variation patterns of HONO mixing ratios were comparable to previous measurements in urban areas (Febo et al. 1996; Alicke et al. 2003; Acker et al. 2006; Yu et al. 2009).

The HONO mixing ratios during the whole campaign ranged from $44 \mathrm{ppt}$ to $7.0 \mathrm{ppb}$ with a mean value of $1.3 \mathrm{ppb}$. A mean concentration of $1.1 \mathrm{ppb}$ has been measured previously at the same location from October 2004 to January 2005
(Hao et al. 2006) and a mean value of $0.92 \mathrm{ppb}$ has been reported from 2 years observations between August 2010 and June 2012 (Wang et al. 2013). It should be mentioned that the HONO concentration levels at this location have been observed to be independent from temporal variations such as seasons and months (Wang et al. 2013). HONO mixing ratio peaks during rush hours reached $\sim 7$ and $\sim 5 \mathrm{ppb}$, respectively on 15 and 27 October before sunrise. A rapid decrease of accumulated HONO concentration was observed after sunrise due to photolysis. For the campaign, averaged data maximum and minimum $\mathrm{HONO}$ mixing ratios were $2.2 \mathrm{ppb}$ at around 06:00 LT (local time) and 0.5 ppb around 13:00 LT, respectively (Fig. 6). The mean concentrations during daytime (07:00-17:00 LT) and nighttime (18:00-06:00 LT) periods have been estimated to be 1.0 and $1.5 \mathrm{ppb}$, respectively. Our measurements have been compared with those conducted in the same location previously, between 22 October 2004 and 4 January 2005 (Hao et al. 2006). These authors reported a mean HONO daytime concentration (07:00-17:00 LT) of $0.7 \mathrm{ppb}$ and a mean nighttime concentration (18:00-06:00 LT) of $1.4 \mathrm{ppb}$. They obtained a mean concentration of $0.5 \mathrm{ppb}$ at noontime (11:00-14:00 LT). The observed HONO daytime concentration fell within the range of the previous observations in urban areas and megacities worldwide, 0.05-2.0 ppb (Alicke et al. 2002; Acker et al. 2006; Hao et al. 2006; Kanaya et al. 2007; Elshorbany et al. 2009; Qin et al. 2009).

The minimum HONO concentration was obtained between 11:00 LT and 16:00 LT. The concentration was continuously increasing from 16:00 LT to 04:00 LT the next day from $443 \mathrm{ppt}$ to $2.1 \mathrm{ppb}$. Afterwards, HONO concentration 
remained nearly constant at $2.1 \mathrm{ppb}$ from 04:15 LT to 07:35 LT. Then, it decreased rapidly mainly due to photolysis, reaching the minimum daytime value at 11:00 LT. Resulting from 10 min averaged diurnal data, HONO formation rates (ppb HONO per hour per ppb $\mathrm{NO}_{2}$ ) were estimated to $0.762 \%$ between 15:45 LT and 18:35 LT and decreased to $0.158 \%$ from 18:45 LT to 03:55 LT. The difference between both HONO increase rates may likely due to traffic-related emissions during rush hour higher in the late afternoon than in the evening.

\section{Intercomparison of the three instruments for HONO measurements}

Figure 2 displays the time series of HONO mixing ratios measured by LOPAP (14-29 October), ID-CIMS (14-20 October) and DOAS (17-25 October). The measurements by the three techniques generally tracked each other very well. In this section, mean, daytime (07:00-17:00 LT) and nighttime (18:0006:00 LT) data resulting from LOPAP are compared to CIMS and DOAS during simultaneous observation period (with $N$, the number of data). The data used for intercomparison originated from the raw data of each instrument as follows: LOPAP (1-min sampled data), CIMS (9-s sampled data) and DOAS (3-min sampled data).

\section{LOPAP/CIMS}

Intercomparison between LOPAP and CIMS was conducted between 14 October (18:15 LT) and 20 October 2009 (09:05 LT). During this field study, the LOPAP and the CIMS instruments were not co-located, but rather separated by $50 \mathrm{~m}$ distance due to the infrastructure of the sampling site. LOPAP was deployed on the rooftop of building with an open space while CIMS was installed in an attic at constant room temperature and sampled on the top of this room on the same building. The sampling position of CIMS was around $3 \mathrm{~m}$ higher than that of LOPAP. As shown in Fig. 3, the data from CIMS and LOPAP instruments were well correlated with no systematic biases. However, significant differences of HONO mixing ratios ( $\pm 21 \%$ ) were observed between 17 (18:00 LT) and 18 (12:00 LT) October. The reasons for these differences were unclear but could be related to the sampling position of both instruments. Differences might come from surrounding buildings combined with low wind speed $\left(0-1 \mathrm{~m} \mathrm{~s}^{-1}\right)$. On 5day measurements (14-20 October 2009), the mean concentrations measured by LOPAP and CIMS were $1.46 \mathrm{ppb} \quad(N=$ $6280)$ and $1.38 \mathrm{ppb}(N=44296)$, respectively. Regarding the respective mean HONO daytime concentrations, $0.91 \mathrm{ppb}$ $(N=2385)$ was derived by LOPAP whereas $0.98 \mathrm{ppb}$ $(N=15259)$ was recorded by CIMS. The mean HONO nighttime measurements observed were $1.81 \mathrm{ppb}(N=3498)$ by LOPAP and $1.56 \mathrm{ppb}(N=25359)$ by CIMS. Considering the measurement accuracy of the LOPAP and the CIMS instruments, the intercomparison agreed for the average on the daytime period (within $8 \%$ ). In nighttime period, LOPAP reported higher values than CIMS (within $14 \%$ ) and agreed within the measurement accuracy. The ratio between values reported from both instruments expressed as $\left(\mathrm{HONO}_{\mathrm{LOPAP}} /\right.$ $\left.\mathrm{HONO}_{\mathrm{CIMS}}\right)_{\text {daytime }}$ and $\left(\mathrm{HONO}_{\mathrm{LOPAP}} / \mathrm{HONO}_{\mathrm{CIMS}}\right)_{\text {nighttime, }}$, respectively, during the day and the night were 0.93 and 1.16 . The ratio values reported from daytime and nighttime measurements differed and, therefore, could not be explained solely by a systematic deviation from both instruments. First, HONO concentration is known to be highly variable temporally and spatially (Kurtenbach et al. 2001). Therefore, the observed differences between daytime and nighttime periods may be explained by a diurnal variable influence of local emission sources. Building-related surfaces (i.e. glass, concrete) likely contributed as reactive sites promoting HONO
Fig. 2 Intercomparison of HONO measurements by LOPAP, CIMS and DOAS between 14 and 29 October, 2009 in Shanghai, China
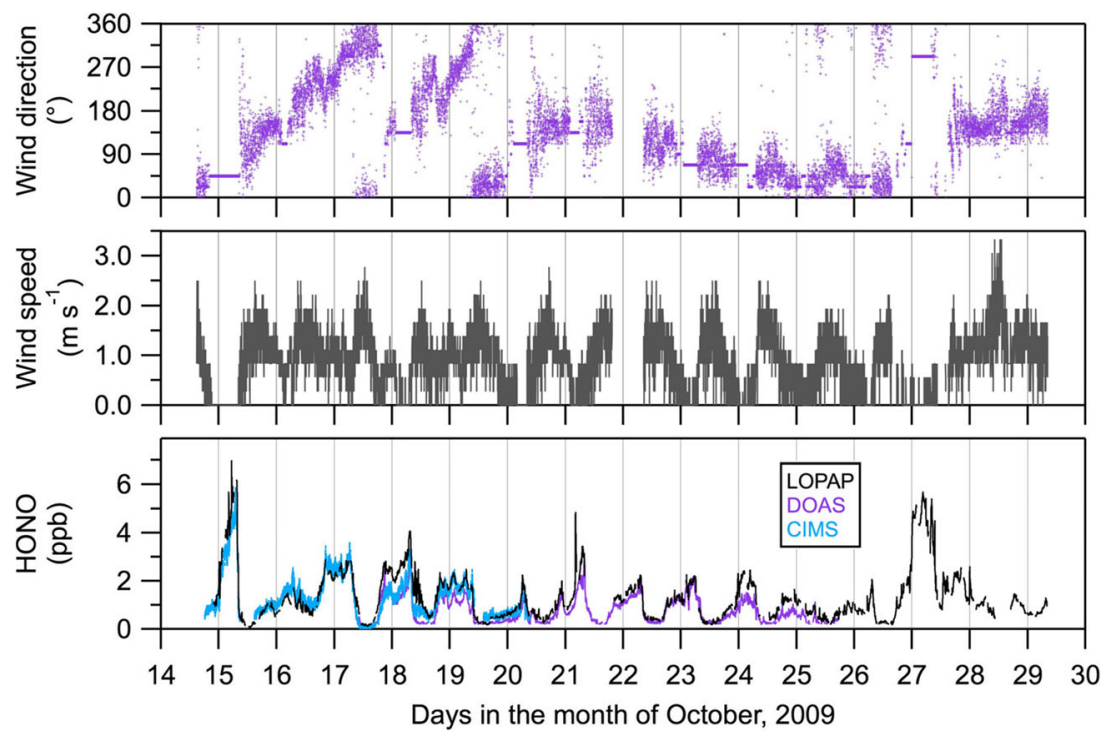
Fig. 3 Intercomparison of HONO measurements by LOPAP and CIMS between 14 and 20 October 2009 in Shanghai, China. The red solid lines represent the linear square analysis applied on the dataset. The absolute error on the slope and $y$-intercept are equivalent to 2 standard deviations $(2 \sigma)$
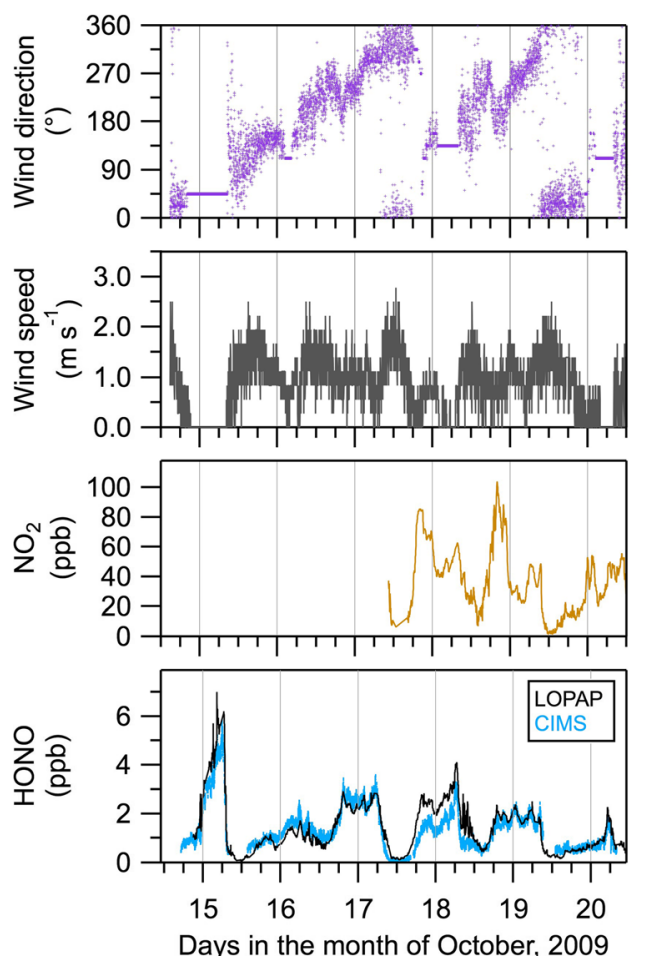

production (Chen et al. 2012). At low wind speed, both instruments (positioned at $50 \mathrm{~m}$ away) might observe different emission sources. Second, the reported ratio values from daytime and nighttime measurements would also indicate different chemical composition of sampled air by the LOPAP and the CIMS instruments. Indeed, this could have led to the sampling of atmospheric species from unknown sources, which could have interfered measurements, also observed by Pinto et al. (2014).

\section{LOPAP/DOAS}

The common period of observation based on the LOPAP and the DOAS measurements was from 17 to 25 October 2009, as shown in Fig. 4. The following observations can be made: (i) the differences between the LOPAP and the DOAS measurements were discernible and more pronounced on 17-19 October and 24-26 October; (ii) HONO levels measured by DOAS were systematically lower than those from LOPAP for all the period which might be attributed to systematic biases. For the same period of intercomparison, the mean HONO concentrations were $1.18 \mathrm{ppb}(N=9064)$ by LOPAP and $0.79 \mathrm{ppb}(N=3510)$ by DOAS. The daytime HONO concentrations were found to be $0.72 \mathrm{ppb}(N=3652)$ by LOPAP and $0.50 \mathrm{ppb}(N=1335)$ by DOAS. The nighttime concentrations were measured at $1.49 \mathrm{ppb}(N=4668)$ by LOPAP and $0.98 \mathrm{ppb}(N=1875)$ by DOAS. The mean values obtained by LOPAP were 31 and $34 \%$ higher than the values reported by DOAS during the daytime and nighttime periods. Taking into account of the measurement accuracy of the DOAS and the LOPAP instruments, the observed differences were considered statistically significant. This would indicate a systematic disagreement between both measurement techniques. It has to be noticed that the air mass compositions measured by both LOPAP and DOAS instruments could differ due to the sampling locations. The inlet of the LOPAP instrument was sensitive to punctual emission and/or production sources from heterogeneous formation of $\mathrm{HONO}$, at close proximity of the building surfaces. In comparison, the DOAS measurement was operated by averaging concentrations along a longpath beam subject to vertical gradients and non-homogeneity of the sampled air masses. Thus, the DOAS instrument was less sensitive to any abrupt changes in the measured HONO concentrations compared to in situ instruments, which might explain overall lower readings from the DOAS instrument. Furthermore, the observed difference could be combined with negative interferences in DOAS retrievals, in addition to different air masses sampled (Kleffmann et al. 2006; Stutz et al. 2010).

\section{Time series of $\mathrm{HONO}, \mathrm{NO}_{2}$ and $\mathrm{HONO} / \mathrm{NO}_{2}$ ratio}

The efficiency of the heterogeneous $\mathrm{NO}_{2}$-HONO conversion is usually determined by the $\mathrm{HONO} / \mathrm{NO}_{2}$ ratio, which is less influenced by transport processes than specific concentrations. During the campaign, $\mathrm{NO}_{2}$ mixing ratios were also measured using DOAS. In this work, $\mathrm{HONO} / \mathrm{NO}_{2}$ ratio has been derived from the HONO measurements from LOPAP and DOAS and 
the measurement of $\mathrm{NO}_{2}$ through DOAS from 17 to 25 October. HONO/ $/ \mathrm{NO}_{2}$ ratio obtained from both LOPAP and DOAS are expressed as $\mathrm{HONO}_{\mathrm{LOPAP}} / \mathrm{NO}_{2}$ and $\mathrm{HONO}$ DOAS $\mathrm{NO}_{2}$ ratios, respectively. Figure 5 shows the time series of HONO (LOPAP and DOAS), $\mathrm{NO}_{2}$ (DOAS) and the obtained $\mathrm{HONO} / \mathrm{NO}_{2}$ ratio at FDU site.

The mean $\mathrm{NO}_{2}$ concentrations during daytime and nighttime measurements were 30.0 and $41.9 \mathrm{ppb}$, respectively. LOPAP measurement led to daytime $\mathrm{HONO}_{\mathrm{LOPAP}} /$ $\mathrm{NO}_{2, \text { DOAS }}=0.032(N=1156)$ whereas nighttime HONO ${ }_{\text {LOPAP }} / \mathrm{NO}_{2}=0.038(N=1605)$. From DOAS measurements, value of $\mathrm{HONO}_{\mathrm{DOAS}} / \mathrm{NO}_{2}=0.019(N=1332)$ during the day and $\mathrm{HONO}_{\mathrm{DOAS}} / \mathrm{NO}_{2}=0.025(N=1873)$ during the night have been obtained. For comparison, the field measurement conducted by Hao et al. (2006) in October 2004 to January 2005 at the same location led to daytime and nighttime $\mathrm{HONO} / \mathrm{NO}_{2}$ ratios of 0.022 and 0.058 , respectively. The obtained $\mathrm{HONO} / \mathrm{NO}_{2}$ ratios were in line with those observed in many urban areas in the world during daytime $\left(\mathrm{HONO} / \mathrm{NO}_{2}=0.003-0.075\right)$ and nighttime $\left(\mathrm{HONO} / \mathrm{NO}_{2}=0.025-0.175\right)$ measurements (Alicke et al. 2002; Acker et al. 2006; Hao et al. 2006; Kanaya et al. 2007; Elshorbany et al. 2009; Qin et al. 2009; Tong et al. 2015).

The HONO and $\mathrm{NO}_{2}$ concentrations exhibited a diurnal variation with low values during the day and high levels during the early morning. The highest $\mathrm{HONO} / \mathrm{NO}_{2}$ ratio was found during the night between 00:00 and 06:00 LT while the lowest was measured during daytime (11:00-16:00 LT). According to the DOAS measurements, $\mathrm{HONO}_{\mathrm{DOAS}} / \mathrm{NO}_{2}$ ratio increased after sunset and kept increasing until midnight. However, distinct peaks around midday were observed on 18 , 19 and 25 October (Fig. 5).

Figure 6 shows the mean diurnal variations of HONO, $\mathrm{NO}_{2}, J_{\mathrm{NO} 2}$ as well as the $\mathrm{HONO} / \mathrm{NO}_{2}$ ratio for the period of 17-25 October 2009. It can be observed that the HONO concentration and $\mathrm{HONO} / \mathrm{NO}_{2}$ ratio increased from sunset throughout the whole night to the early morning due to the combination of local emissions, the heterogeneous conversion of $\mathrm{NO}_{2}$, the lower boundary layer height and the absence of any photolytic process. During the day, the HONO mixing ratios continuously decreased, reaching a minimum in the late afternoon, due to photolytic processes and an increasing vertical mixing within the higher daytime boundary layer. Also, the observed decrease of $\mathrm{HONO} / \mathrm{NO}_{2}$ ratio was due to $\mathrm{HONO}$ photolysis and caused by fresh $\mathrm{NO}_{x}$ emissions during rush hours at low HONO content ( $\mathrm{HONO} / \mathrm{NO}_{x} \sim 1 \%$ (Kurtenbach et al. 2001)). It can also be observed that $\mathrm{HONO} / \mathrm{NO}_{2}$ ratio tended to increase during the day (between 13:00 and 15:00 LT). This may show the HONO formation efficiency for low $\mathrm{NO}_{2}$ concentration in agreement with some laboratory studies relating the HONO formation efficiency from the heterogeneous $\mathrm{NO}_{2}$ conversion on photo-enhanced surfaces (George et al. 2005; Stemmler et al. 2006). Another possible explanation for the high levels might be the local emissions/productions such as
Fig. 4 Intercomparison of HONO measurements by LOPAP and DOAS between 17 and 25 October 2009 in Shanghai, China. The red solid lines represent the linear square analysis applied on the dataset. The absolute error on the slope and $y$-intercept are equivalent to 2 standard deviations $(2 \sigma)$
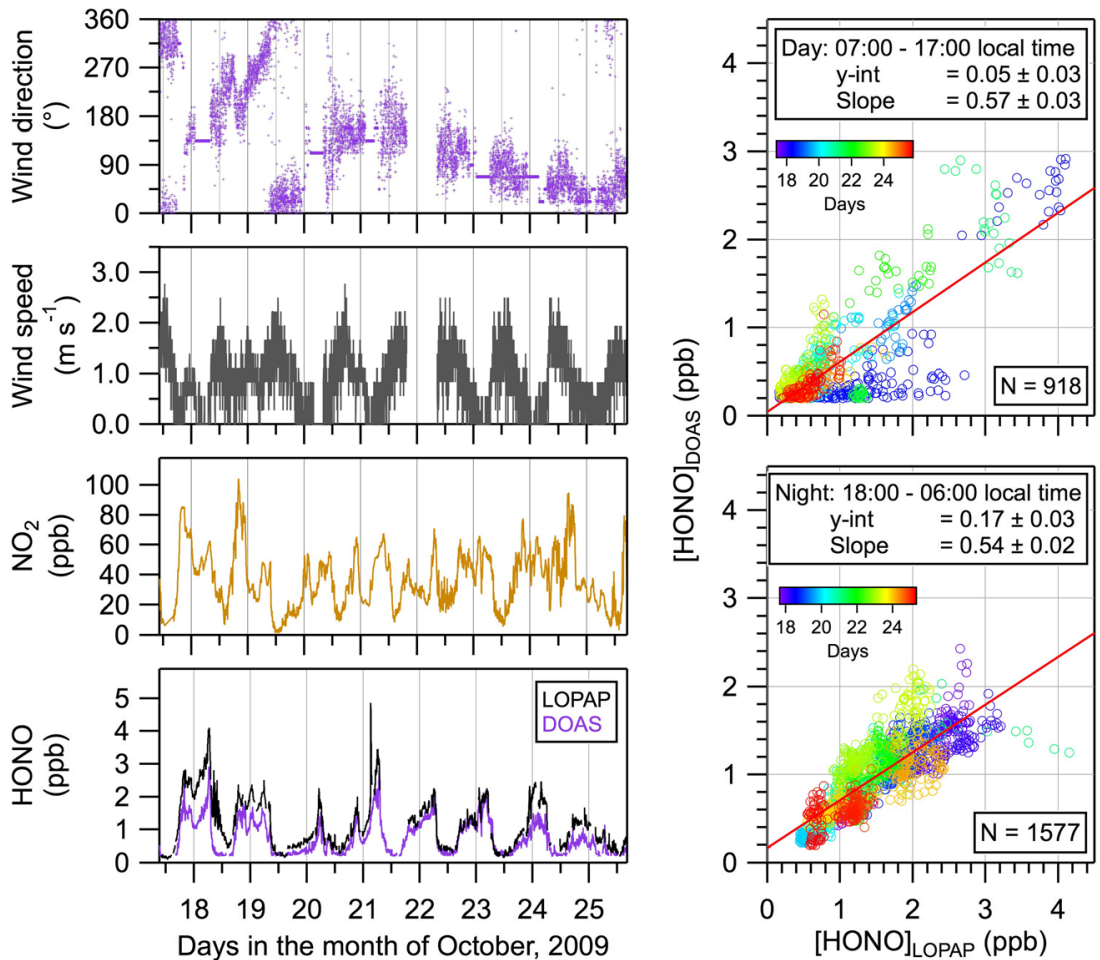
Fig. 5 Time series of $\mathrm{NO}_{2}$ photolysis rate $\left(J_{\mathrm{NO} 2}\right), \mathrm{NO}_{2}$ (DOAS) and $\mathrm{HONO} / \mathrm{NO}_{2}$ ratio during the observation period of 17-25 October in Shanghai, China

homogeneous reaction and/or heterogeneous reactions of $\mathrm{NO}_{2}$ on aerosol and ground surfaces.

$\mathrm{NO}_{2}$ mixing ratios showed a similar diurnal behaviour with $\mathrm{HONO} . \mathrm{NO}_{2}$ mixing ratios were high in the early morning due to rush hour emissions and a shallow boundary layer. After that, $\mathrm{NO}_{2}$ decreased from a maximum at 07:00-08:00 LT to a minimum around noontime and then increased during the rush hour period in the evening. The
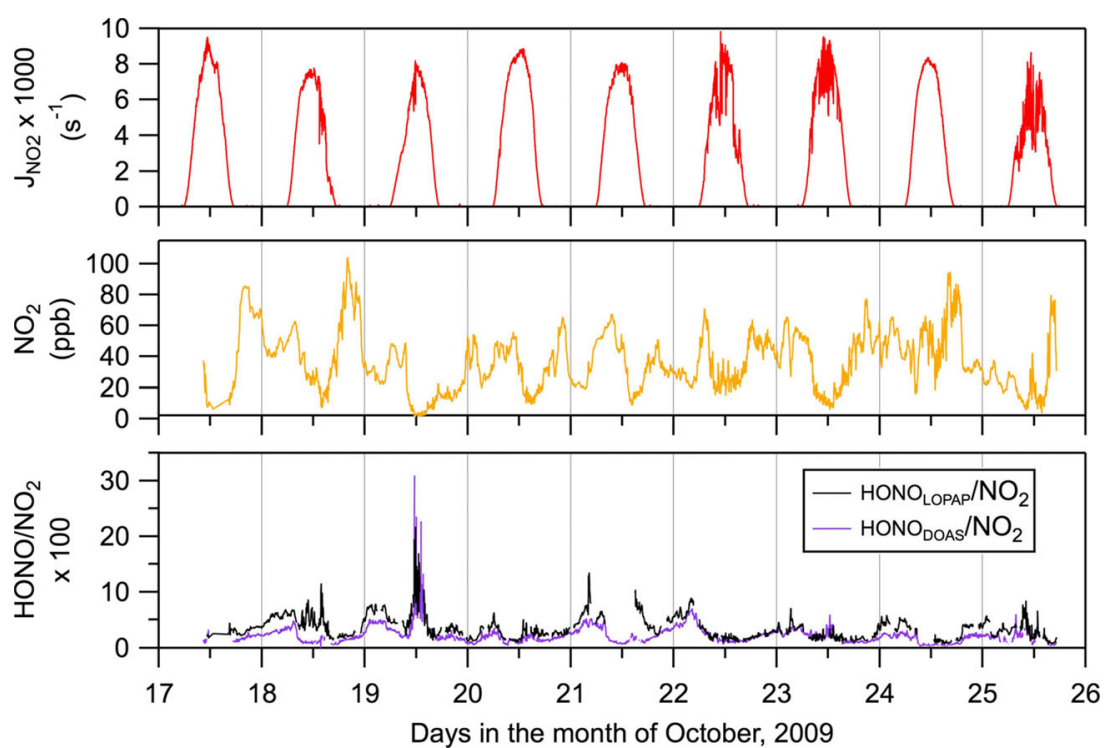

Fig. 6 Mean diurnal variation pattern of $\mathrm{HONO}, \mathrm{NO}_{2}, \mathrm{~J}_{\mathrm{NO} 2}$ and $\mathrm{HONO} / \mathrm{NO}_{2}$ ratio during the period from 17 to 25 October 2009. The data are 1-h averaged
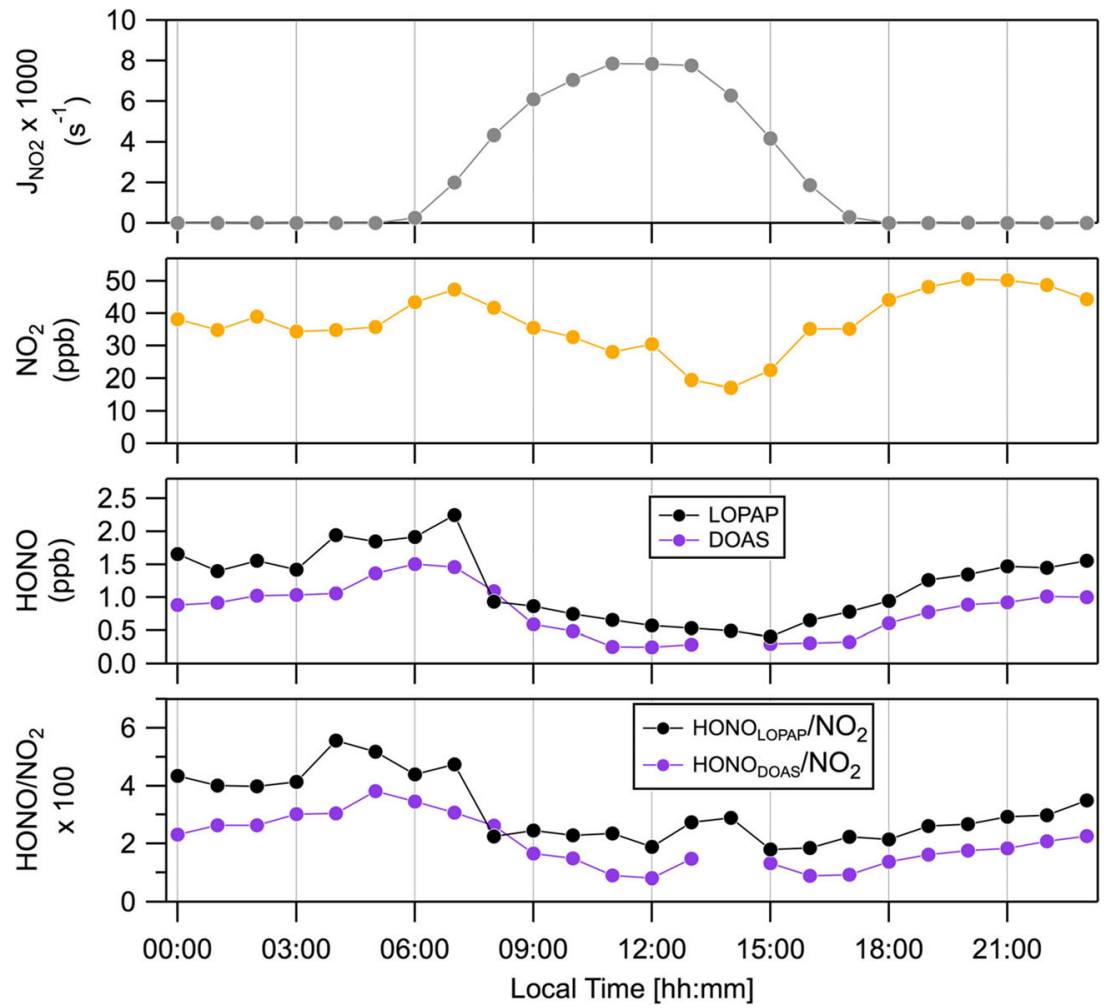


\section{Relative humidity dependence of the nighttime $\mathrm{HONO} / \mathrm{NO}_{2}$ ratio}

The role played by the relative humidity $(\mathrm{RH})$ in the nocturnal HONO formation has been reported in several field measurements (Stutz et al. 2004; Hao et al. 2006; Yu et al. 2009; Wang et al. 2013). A little is known about the involvement of water in the $\mathrm{NO}_{2}$ to $\mathrm{HONO}$ conversion under the dark. Besides, as mentioned earlier (Section "Time series of $\mathrm{HONO}, \mathrm{NO}_{2}$ and $\mathrm{HONO} / \mathrm{NO}_{2}$ ratio"), several environmental parameters could influence the time-concentration profiles of HONO and $\mathrm{HONO} / \mathrm{NO}_{2}$ ratio during the night. $\mathrm{HONO} / \mathrm{NO}_{2}$ ratio observed a continuous increase during the night. In parallel, the humidity independently increased during nighttime, caused by the radiative cooling of the surface layer (where the measurements took place). As both independent processes, the observed positive humidity dependence of $\mathrm{HONO} / \mathrm{NO}_{2}$ should not be a proof of any specific chemical mechanism humidity related. Previous studies have shown that the maximum $\mathrm{HONO} / \mathrm{NO}_{2}$ ratio was positively dependent to $\mathrm{RH}$ below $70 \%$ and negatively dependent when $\mathrm{RH}>70 \%$ in Shanghai area (Hao et al. 2006; Wang et al. 2013). In addition, a positive dependence of $\mathrm{HONO} / \mathrm{NO}_{2}$ with $\mathrm{RH}$ was also observed in the study of Hou et al. (2015) for $\mathrm{RH} \leq 65 \%$ in Beijing area. Based on LOPAP and DOAS measurements, the correlation between $\mathrm{RH}$ and the HONO formation rate through the reaction of $\mathrm{NO}_{2}$ with adsorbed water on surfaces during the night has been examined. On a kinetic basis, HONO formation rate has been reported to be pseudo first order in $\mathrm{NO}_{2}$, also dependent of the adsorbed $\mathrm{H}_{2} \mathrm{O}$ and the surface to volume ratio (Kleffmann et al. 1998; FinlaysonPitts et al. 2003). However, the 1-h averaged data for particles did not allow us to conclude about any contribution of particle concentration to the HONO formation in Shanghai during our measurement campaign.

Nocturnal HONO formation rate has been determined based on the linear increase of the $\mathrm{HONO} / \mathrm{NO}_{2}$ ratio in function of time in the periods of 18:00-00:00 LT and 00:0006:00 LT. The dependence of relative humidity on HONO formation rate was parameterized according to the approach used by Alicke et al. (2002), where an effective pseudo-first order rate constant, $k$, has been derived according to:

$k=\frac{d\left([\mathrm{HONO}] /\left[\mathrm{NO}_{2}\right]\right.}{d t}$

Figure $7 \mathrm{a}, \mathrm{b}$ shows the plot of HONO formation rate constant $\left(d\left([\mathrm{HONO}] /\left[\mathrm{NO}_{2}\right]\right) / d t\right)$ versus $\mathrm{RH}$ with $\mathrm{HONO}$ concentrations obtained from LOPAP and DOAS measurements, respectively. DOAS measurements showed that for the 25-55 \% RH range, HONO formation exhibited a positive dependence with RH. The highest value of
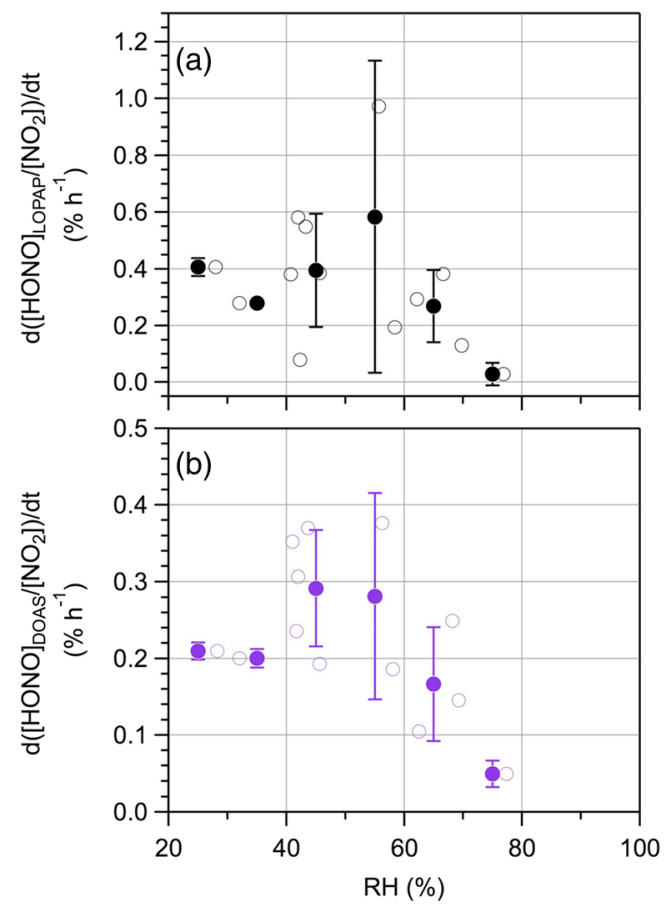

Fig. 7 HONO formation rate from LOPAP measurements (a) and DOAS measurements (b) ratios versus the relative humidity $(\mathrm{RH})$ during nighttime measurements in Shanghai, China. The open circles represent the individual measurements for each nighttime period (18:00-00:00 LT and 00:00-06:00 LT). Filled circles represent the average values of HONO formation rate coefficients in the relative humidity $(\mathrm{RH})$ ranges $(20$ $30 \%, 30-40 \%, 40-50 \%, 50-60 \%, 60-70 \%$ and $70-80 \%)$. The errors bars originated from 1 standard deviation on the average $(1 \sigma)$

$d\left([\mathrm{HONO}] /\left[\mathrm{NO}_{2}\right]\right) / d t$ ratio was obtained for $45-55 \% \mathrm{RH}$ range. For $\mathrm{RH}>55 \%$, HONO formation ratio showed a negative dependence with RH. From LOPAP measurements, the dependence of $\mathrm{HONO} / \mathrm{NO}_{2}$ with $\mathrm{RH}$ showed a similar behaviour with a positive dependence reaching a maximum $(\mathrm{RH}=55 \%)$ and decreased for $\mathrm{RH}>55 \%$.

By comparison between both techniques, higher values of $d\left([\mathrm{HONO}] /\left[\mathrm{NO}_{2}\right]\right) / d t$ ratio were obtained with LOPAP than for DOAS measurements for the same RH value. In addition, based on the DOAS measurements, a lower $\mathrm{HONO} / \mathrm{NO}_{2}$ ratio was obtained in this work compared to that of the study of Hao et al. (2006) conducted 5 years ago for $\mathrm{RH}>50 \%$. The same trend was also observed for the mean $\mathrm{HONO} / \mathrm{NO}_{2}$ ratio (Table S1). This suggests that the primary source of HONO might have a greater contribution to the HONO ambient levels than its secondary sources over the past years."

On Fig. 7, the positive dependence of $\mathrm{HONO} / \mathrm{NO}_{2}$ with $\mathrm{RH}(25 \% \leq \mathrm{RH} \leq 55 \%)$ is consistent with an efficient $\mathrm{NO}_{2}$ HONO conversion on wet surfaces. Moreover, the observed negative dependence $(\mathrm{RH} \geq 55 \%)$ could be explained by the inhibiting effect of relative humidity on HONO formation rate. Lammel (1999) reported the number of monolayers of water as a function of relative humidity for different environmental surfaces (i.e. soil). For RH $>50 \%$, the numbers 
monolayers would increase quickly from $\sim 1.5$ to $\sim 3-5$ monolayers at $\mathrm{RH}=90 \%$. At high $\mathrm{RH}$ values $(\mathrm{RH}=95 \%)$, multiple adsorbed water layers are present and eventually liquid films on the surface, which would make the heterogeneous conversion of $\mathrm{NO}_{2}$ to $\mathrm{HONO}$ unfavoured. At high $\mathrm{RH}, \mathrm{HONO}$ would be dissolved in adsorbed water, leading to a decrease of HONO concentration in the gas phase, and thus $\mathrm{HONO} / \mathrm{NO}_{2}$ ratio values, as observed in the present field study (Lammel 1999; Finlayson-Pitts et al. 2003; Stutz et al. 2004). HONO formation rate have been also found to be wetness surface dependent in previous field measurements (Stutz et al. 2004; Hao et al. 2006; Yu et al. 2009; Wang et al. 2013).

\section{Conclusions}

A field campaign was carried out in the urban area of Shanghai, Eastern China, during the last 2 weeks of October 2009. HONO mixing ratio has been continuously measured using three complementary analytical techniques (LOPAP, CIMS and DOAS). The observed mean concentration of HONO was found to be $1.3 \mathrm{ppb}$, coherent with the other measurements (Hao et al. 2006; Wang et al. 2013). Resulted from the LOPAP measurements, the mean HONO daytime and nighttime mixing ratios have been measured at 1.0 and $1.5 \mathrm{ppb}$, respectively, in agreement with many observations in urban areas in the world. Overall, the HONO measurement exhibited a good agreement and instruments tracked each other very well, reproducing similar daily HONO patterns. During this campaign, the LOPAP and the CIMS measurements agreed within 8 and $14 \%$ during the day and the night, respectively. However, daytime and nighttime $\mathrm{HONO}_{\mathrm{LOPAP}} /$ $\mathrm{HONO}_{\mathrm{CIMS}}$ ratios showed a non-systematic disagreement, about 0.93 and 1.16 , respectively, suggesting the sampling of different chemical species. Comparison of LOPAP and DOAS measurements showed a similar disagreement between the day and the night, about 31 and $34 \%$, respectively, where LOPAP measured higher values than DOAS. Possible explanations were attributed to the sampling locations between the local and the long-path samplings or/and negative interferences affecting the DOAS data retrievals.

Using the data obtained by the LOPAP and the DOAS instruments for HONO and those from DOAS for $\mathrm{NO}_{2}$, $\mathrm{HONO} / \mathrm{NO}_{2}$ ratio has been estimated. High values of $\mathrm{HONO} / \mathrm{NO}_{2}$ ratio were observed, they were in the same order of magnitude as those previously reported in other high polluted cities. The correlation of $\mathrm{HONO} / \mathrm{NO}_{2}$ ratio with the relative humidity during the nighttime period showed a strong dependence. This suggests that $\mathrm{H}_{2} \mathrm{O}$ played an important role in HONO formation through nighttime chemistry. Although the lack of data on particle concentration, particles might contribute through the heterogeneous chemistry onto HONO formation as reported previously (Hao et al. 2006). Hence, further investigations are of paramount importance to improve our understanding of atmospheric chemical processes controlling the HONO concentration levels in different areas around the globe.

Acknowledgments This work was supported by Centre National de la Recherche Scientifique-Institute of Ecology and Environment (CNRSINEE, France) through the Sino-French program, the Labex Voltaire (ANR-10-LABX-100-01), the Department of Environmental Science \& Engineering of Fudan University (Shanghai) and the Chinese Academy of Science (Beijing). We thank the Pudong Meteorological Station for the particulate matter $\left(\mathrm{PM}_{1}, \mathrm{PM}_{2.5}\right.$ and $\left.\mathrm{PM}_{10}\right)$ data. $\mathrm{BZ}$ thanks the financial support from the National Natural Science Foundation of China under Grant No. 21277029, 21477021. JZ acknowledges the support from National Natural Science Foundation of China (41275142 and 41575122) and Jiangsu Provincial Specially-Appointed Professors Foundation.

\section{Compliance with ethical standards}

Conflict of interest The authors declare that they have no conflict of interest.

\section{References}

Acker K, Febo A, Trick S, Perrino C, Bruno P, Wiesen P, Möller D, Wieprecht W, Auel R, Giusto M, Geyer A, Platt U, Allegrini I (2006) Nitrous acid in the urban area of Rome. Atmos Environ 40(17):3123-3133. doi:10.1016/j.atmosenv.2006.01.028

Alicke B, Platt U, Stutz J (2002) Impact of nitrous acid photolysis on the total hydroxyl radical budget during the Limitation of Oxidant Production/Pianura Padana Produzione di Ozono study in Milan. J Geophys Res 107(D22):8196. doi:10.1029/2000jd000075

Alicke B, Geyer A, Hofzumahaus A, Holland F, Konrad S, Pätz H-W, Schäfer J, Stutz J, Volz-Thomas A, Platt U (2003) OH formation by HONO photolysis during the BERLIOZ experiment. J Geophys Res 108(D4):8247. doi:10.1029/2001JD000579

Ammann M, Kalberer M, Jost DT, Tobler L, Rössler E, Piguet D, Gäggeler HW, Baltensperger U (1998) Heterogeneous production of nitrous acid on soot in polluted air masses. Nature 395:157-160

Arens F, Gutzwiller L, Baltensperger U, Gäggeler HW, Ammann M (2001) Heterogeneous reaction of $\mathrm{NO}_{2}$ on diesel soot particles. Environ Sci Technol 35(11):2191-2199. doi:10.1021/es000207s

Aumont B, Madronich S, Ammann M, Kalberer M, Baltensperger U, Hauglustaine D, Brocheton $\mathrm{F}$ (1999) On the $\mathrm{NO}_{2}+$ soot reaction in the atmosphere. J Geophys Res 104(D1):1729-1736. doi:10.1029/ 1998JD100023

Aumont B, Chervier F, Laval S (2003) Contribution of HONO sources to the $\mathrm{NO}_{\mathrm{X}} / \mathrm{HO}_{\mathrm{X}} / \mathrm{O}_{3}$ chemistry in the polluted boundary layer. Atmos Environ 37(4):487-498. doi:10.1016/s1352-2310(02)00920-2

Chen H, Nanayakkara CE, Grassian VH (2012) Titanium dioxide photocatalysis in atmospheric chemistry. Chem Rev 112(11): 5919-5948. doi:10.1021/cr3002092

Elshorbany YF, Kurtenbach R, Wiesen P, Lissi E, Rubio M, Villena G, Gramsch E, Rickard AR, Pilling MJ, Kleffmann J (2009) Oxidation capacity of the city air of Santiago, Chile. Atmos Chem Phys 9: 2257-2273

Febo A, Perrino C, Allegrini I (1996) Measurement of nitrous acid in Milan, Italy, by DOAS and diffusion denuders. Atmos Environ 30(21):3599-3609 
Finlayson-Pitts BJ, Wingen LM, Summer AL, Syomin D, Ramazan KA (2003) The heterogeneous hydrolysis of $\mathrm{NO}_{2}$ in laboratory systems and in outdoor and indoor atmospheres: an integrated mechanism. Phys Chem Chem Phys 5:223-242

Fortner EC, Zhao J, Zhang R (2004) Development of ion drift-chemical ionization mass spectrometry. Anal Chem 76(18):5436-5440

George C, Strekowski RS, Kleffmann J, Stemmler K, Ammann M (2005) Photoenhanced uptake of gaseous $\mathrm{NO}_{2}$ on solid organic compounds: a photochemical source of HONO? Faraday Discuss 130: 195-210. doi:10.1039/B417888M

Hao N, Zhou B, Chen D, Chen L-M (2006) Observations of nitrous acid and its relative humidity dependence in Shanghai. J Environ Sci 18(5):910-915

Heland J, Kleffmann J, Kurtenbach R, Wiesen P (2001) A new instrument to measure gaseous nitrous acid (HONO) in the atmosphere. Environ Sci Technol 35(15):3207-3212

Hirokawa J, Kato T, Mafuné F (2009) In situ measurements of atmospheric nitrous acid by chemical ionization mass spectrometry using chloride ion transfer reactions. Anal Chem 81(20):8380-8386. doi:10. $1021 / \mathrm{ac} 901117 \mathrm{~b}$

Hou S, Tong S, Ge M, An J (2015) Comparison of atmospheric nitrous acid during severe haze and clean periods in Beijing, China. Atmos Environ. doi:10.1016/j.atmosenv.2015.06.023

Huang X-F, He L-Y, Xue L, Sun T-L, Zeng L-W, Gong Z-H, Hu M, Zhu T (2012) Highly time-resolved chemical characterization of atmospheric fine particles during 2010 Shanghai World Expo. Atmos Chem Phys 12(11):4897-4907. doi:10.5194/acp-12-4897-2012

Kanaya Y, Cao R, Akimoto H, Fukuda M, Komazaki Y, Yokouchi Y, Koike M, Tanimoto H, Takegawa N, Kondo Y (2007) Urban photochemistry in central Tokyo: 1 . Observed and modeled $\mathrm{OH}$ and $\mathrm{HO}_{2}$ radical concentrations during the winter and summer of 2004 . J Geophys Res 112(D21312). doi:10.1029/2007JD008670

Kirchstetter TW, Harley RA, Littlejohn D (1996) Measurement of nitrous acid in motor vehicle exhaust. Environ Sci Technol 30(9):28432849. doi:10.1021/es960135y

Kleffmann J, Becker KH, Wiesen P (1998) Investigation of the heterogeneous $\mathrm{NO}_{2}$ conversion on perchloric acid surfaces. J Chem Soc Faraday Trans 94:3289-3292

Kleffmann J, Heland J, Kurtenbach R, Lörzer J, Wiesen P (2002) A new instrument (LOPAP) for the detection of nitrous acid (HONO). Environ Sci Pollut Res Spec Issue 4:48-54

Kleffmann J, Lörzer JC, Kern C, Trick S, Volkamer R, Rodenas M, Wirtz $\mathrm{K}$ (2006) Intercomparison of the DOAS and LOPAP techniques for the detection of nitrous acid (HONO). Atmos Environ 40:3640 3652

Kurtenbach R, Becker KH, Gomes JAG, Kleffmann J, Lörzer JC, Spittler M, Wiesen P, Ackermann R, Geyer A, Platt U (2001) Investigations of emissions and heterogeneous formation of $\mathrm{HONO}$ in a road traffic tunnel. Atmos Environ 35(20):3385-3394

Lammel G (1999) Formation of nitrous acid parameterization and comparison with observations, Report 286, Max-Planck-Institut für Meteorologie, Hamburg, Germany, $36 \mathrm{pp}$.

Levy M, Zhang R, Zheng J, Zhang AL, Xu W, Gomez-Hernandez M, Wang Y, Olaguer E (2014) Measurements of nitrous acid (HONO) using ion drift-chemical ionization mass spectrometry during the 2009 SHARP field campaign. Atmos Environ 94:231-240. doi:10. 1016/j.atmosenv.2014.05.024

Li L, Chen J, Chen H, Yang X, Tang Y, Zhang R (2011) Monitoring optical properties of aerosols with cavity ring-down spectroscopy. J Aerosol Sci 42(4):277-284

Mérienne MF, Jenouvrier A, Coquart B (1995) The $\mathrm{NO}_{2}$ absorption spectrum. I: absorption cross-sections at ambient temperature in the 300 $500 \mathrm{~nm}$ region. J Atmos Chem 20(3):281-297. doi:10.1007/ BF00694498

Ndour M, D'Anna B, George C, Ka O, Balkanski Y, Kleffmann J, Stemmler K, Ammann M (2008) Photoenhanced uptake of
$\mathrm{NO}_{2}$ on mineral dust: laboratory experiments and model simulations. Geophys Res Lett 35(L05812). doi:10.1029/ 2007GL032006

Pinto JP, Dibb J, Lee BH, Rappenglück B, Wood EC, Levy M, Zhang RY, Lefer B, Ren XR, Stutz J, Tsai C, Ackermann L, Golovko J, Herndon SC, Oakes M, Meng QY, Munger JW, Zahniser M, Zheng J (2014) Intercomparison of field measurements of nitrous acid (HONO) during the SHARP campaign. J Geophys Res 119: 5583-5601. doi:10.1002/2013JD020287

Qin M, Xie P, Su H, Gu J, Peng F, Li S, Zeng L, Liu J, Liu W, Zhang Y (2009) An observational study of the $\mathrm{HONO}-\mathrm{NO}_{2}$ coupling at an urban site in Guangzhou City, South China. Atmos Environ 43(36): $5731-5742$

Spindler G, Hesper J, Brüggemann E, Dubois R, Müller T, Herrmann H (2003) Wet annular denuder measurements of nitrous acid: laboratory study of the artefact reaction of $\mathrm{NO}_{2}$ with $\mathrm{S}(\mathrm{IV})$ in aqueous solution and comparison with field measurements. Atmos Environ 37(19):2643-2662

Staffelbach T, Neftel A, Horowitz LW (1997) Photochemical oxidant formation over southern Switzerland: 2. Model results. J Geophys Res 102(D19):23363-23373. doi:10.1029/97JD00932

Stemmler K, Ammann M, Donders C, Kleffmann J, George C (2006) Photosensitized reduction of nitrogen dioxide on humic acid as a source of nitrous acid. Nature 440:195-198. doi:10.1038/ nature 04603

Stutz J, Kim ES, Platt U, Bruno P, Perrino C, Febo A (2000) UV-visible absorption cross sections of nitrous acid. J Geophys Res 105(D11): 14585-14592. doi:10.1029/2000JD900003

Stutz J, Alicke B, Ackermann R, Geyer A, Wang S, White AB, Williams EJ, Spicer CW, Fast JD (2004) Relative humidity dependence of HONO chemistry in urban areas. J Geophys Res 109(D3), D03307. doi:10.1029/2003JD004135

Stutz J, Oh HJ, Whitlow SI, Anderson C, Dibb JE, Flynn JH, Rappenglück B, Lefer B (2010) Simultaneous DOAS and mistchamber IC measurements of HONO in Houston, TX. Atmos Environ 44(33):4090-4098. doi:10.1016/j.atmosenv.2009.02.003

Su H, Cheng Y, Oswald R, Behrendt T, Trebs I, Meixner FX, Andreae MO, Cheng P, Zhang Y, Pöschl U (2011) Soil nitrite as a source of atmospheric HONO and $\mathrm{OH}$ radicals. Science 333(6049):16161618. doi:10.1126/science. 1207687

Tong S, Hou S, Zhang Y, Chu B, Liu Y, He H, Zhao P, Ge M (2015) Comparisons of measured nitrous acid (HONO) concentrations in a pollution period at urban and suburban Beijing, in autumn of 2014. Sci China Chem 58(9):1393-1402

Volkamer R, Sheehy P, Molina LT, Molina MJ (2010) Oxidative capacity of the Mexico City atmosphere-Part 1: a radical source perspective. Atmos Chem Phys 10:6969-6991. doi:10.5194/acp-10-69692010

Wang S, Zhou R, Zhao H, Wang Z, Chen L, Zhou B (2013) Long-term observation of atmospheric nitrous acid (HONO) and its implication to local $\mathrm{NO}_{2}$ levels in Shanghai, China. Atmos Environ 77:718-724. doi:10.1016/j.atmosenv.2013.05.071

Winer AM, Biermann HW (1994) Long pathlength differential optical absorption spectroscopy (DOAS) measurements of gaseous $\mathrm{HONO}, \mathrm{NO}_{2}$ and $\mathrm{HCNO}$ in the California South Coast Air Basin. Res Chem Intermed 20(3-5):423-445. doi: 10.1163/156856794X00405

Yu Y, Geyer A, Xie P, Galle B, Chen L, Platt U (2004) Observations of carbon disulfide by differential optical absorption spectroscopy in Shanghai. Geophys Res Lett 31(11), L11107. doi:10.1029/ 2004GL019543

Yu Y, Galle B, Panday A, Hodson E, Prinn R, Wang S (2009) Observations of high rates of $\mathrm{NO}_{2}-\mathrm{HONO}$ conversion in the nocturnal atmospheric boundary layer in Kathmandu, Nepal. Atmos Chem Phys 9:6401-6415. doi:10.5194/acp-9-6401-2009 
Zhou X, Beine HJ, Honrath RE, Fuentes JD, Simpson W, Shepson PB, Bottenheim JW (2001) Snowpack photochemical production of HONO: a major source of $\mathrm{OH}$ in the Arctic boundary layer in springtime. Geophys Res Lett 28(21):4087-4090. doi:10.1029/ 2001GL013531

Zhou X, Gao H, He Y, Huang G, Bertman SB, Civerolo K, Schwab J (2003) Nitric acid photolysis on surfaces in low- $\mathrm{NO}_{\mathrm{X}}$ environments: significant atmospheric implications. Geophys Res Lett 30(23): 2217. doi:10.1029/2003GL018620

Ziemba LD, Dibb JE, Griffin RJ, Anderson CH, Whitlow SI, Lefer BL, Rappenglück B, Flynn J (2010) Heterogeneous conversion of nitric acid to nitrous acid on the surface of primary organic aerosol in an urban atmosphere. Atmos Environ 44(33):40814089 